\title{
What Is Philosophy?
}


This page intentionally left blank 


\section{What Is Philosophy?}

Edited by C. P. Ragland and Sarah Heidt 
Published with assistance from the Ernst Cassirer Publications Fund.

Copyright (ㅇ 2001 by Yale University. "What Is Philosophy?" by Barry Stroud, copyright $(\mathcal{C} 2001$ by Barry Stroud

"Reason, Expression, and the Philosophic Enterprise," by Robert Brandom, copyright (C) by Robert Brandom A longer version of "Public Philosophy and International Feminism," by Martha C. Nussbaum, appeared in Ethics 108 (July 1998): 762-796, () 1998 by The University of Chicago. All rights reserved.

This book may not be reproduced, in whole or in part, including illustrations, in any form (beyond that copying permitted by Sections 107 and 108 of the U.S. Copyright Law and except by reviewers for the public press), without written permission from the publishers. Designed by Sonia L. Shannon

Set in Bulmer type by Keystone Typesetting, Orwigsburg, Penn.
Library of Congress Cataloging-inPublication Data

What is philosophy? / edited by C. P. Ragland and Sarah Heidt.

p. cm.

Includes bibliographical references and index.

ISBN: 978-0-300-08794-9

1. Philosophy. I. Ragland, C. P., 1970II. Heidt, Sarah L., 1968- III. Title.

B29. W45 2001

$100-\mathrm{dc} 21$

oo-012597

A catalogue record for this book is available from the British Library.

The paper in this book meets the guidelines for permanence and durability of the Committee on Production Guidelines for Book Longevity of the Council on Library Resources. 